\title{
Pengaruh Inflasi, Suku Bunga, dan Nilai Tukar Rupiah Terhadap Return Saham Pada PT. Astra International Yang Terdaftar Di Bursa Efek Indonesia
}

\author{
Syahri Ayu Fadhilah ${ }^{1}$, Hendry Saladin ${ }^{2}$, Emilda $^{3}$ \\ ${ }^{1}$ Fakultas Ekonomi dan Bisnis Universitas PGRI Palembang, Syahriayufadh98@gmail.com \\ ${ }^{2}$ Fakultas Ekonomi dan Bisnis Universitas PGRI Palembang, hendrysaladin62@gmail.com \\ ${ }^{3}$ Fakultas Ekonomi dan Bisnis Universitas PGRI Palembang, Emilzahra@gmail.com
}

\begin{abstract}
ABSTRAK
Penelitian ini bertujuan untuk mengetahui pengaruh inflasi, suku bunga, dan nilai tukar rupiah terhadap return saham pada PT. Astra International yang terdaftar di Bursa Efek Indonesia periode 2009-2018. Data yang diamati merupakan laporan kondisi keuangan dari faktor eksternal yaitu inflasi, suku bunga, dan nilai tukar rupiah. Populasi adalah return pada saham PT. Astra International yang terdaftar di Bursa Efek Indonesia, sedangkan sampel menggunakan purposive judgment sampling dengan kreteria perusahaan terdaftar di Bursa Efek Indonesia, sahamnya aktif diperdagangkan, dan data tersedia di Bursa Efek Indonesia dan data inflasi, suku bunga, dan nilai tukar rupiah dari Bank Indonesia periode 2009-2018. Analisis dan pembahasan dilakukan menggunakan metode statistik kuantitatif dengan analisis regresi berganda, Uji t, Uji F, dan Koefisien determinasi yang diuji dengan uji asumsi klasik. Hasil pembahasan diketahui secara parsial signifikan untuk variabel inflasi sebesar $0,55>0,05$ sehingga disimpulkan bahwa $\mathrm{H}_{0}$ diterima dan $\mathrm{H}_{\mathrm{a}}$ ditolak yang artinya tidak terdapat pengaruh signifikan dari variabel inflasi terhadap return saham, hasil dari variabel suku bunga diperoleh hasil sebesar 0,012 $<0,05$ sehingga disimpulkan bahwa terdapat pengaruh signifikan dari variabel suku bunga terhadap return saham. Variabel nilai tukar diperoleh hasil sebesar $0369>0,05$ sehingga disimpulkan bahwa tidak terdapat pengaruh signifikan dari variabel nilai tukar rupiah terhadap return saham. Sedangkan secara simultan hasil penelitian menunjukkan bahwa variabel inflasi, suku bunga, dan nilai tukar rupiah terhadap return saham diperoleh hasil sebesar 0,044<0,05 dengan demikian dapat disimpulkan bahwa secara simultan terdapat pengaruh signifikan dari variabel inflasi, suku bunga, dan nilai tukar rupiah terhadap return saham.
\end{abstract}

Kata Kunci : Inflasi, Suku Bunga, Nilai Tukar Rupiah, Return Saham

\begin{abstract}
This study aims to determine the effect of inflation, interest rates, and the rupiah exchange rate on stock returns at PT. Astra International listed on the Indonesia Stock Exchange for the period 20092018. The observed data are financial condition reports from external factors, namely inflation, interest rates, and the rupiah exchange rate. Population is the return on PT. Astra International is listed on the Indonesia Stock Exchange, while the sample uses purposive judgment sampling with company criteria listed on the Indonesia Stock Exchange, its shares are actively traded, and data is available on the Indonesia Stock Exchange and inflation data, interest rates, and rupiah exchange rates from Bank Indonesia period 2009-2018. Analysis and discussion are carried out using quantitative statistical methods with multiple regression analysis, $t$ test, $F$ test, and the coefficient of determination tested with the classic assumption test. The results of the discussion are known to be partially significant for the inflation variable of $0.55>0.05$ so that it is concluded that $\mathrm{HO}$ is accepted and $\mathrm{Ha}$ is rejected, which means there is no significant influence of the inflation variable on stock returns, the results of the interest rate variable are obtained results of $0.012<0,05$ so it can be concluded that there is a significant influence of the variable interest rates on stock returns. The exchange rate variable obtained results of 0369> 0.05 so it can be concluded that there is no significant effect of the rupiah exchange rate variable on stock returns. While simultaneously the results of the study showed that the variables of inflation, interest rates, and the rupiah exchange rate on stock returns obtained results of $0.044<0.05$ thus it can be concluded that simultaneously there is a significant influence of the variables of inflation, interest rates, and the rupiah exchange rate on stock returns.
\end{abstract}

Keywords: Inflation, Interest Rates, Rupiah Exchange Rates, Stock Returns 


\section{A. PENDAHULUAN}

Investasi di indonesia dimulai tahun 1967 dengan Undang-undang nomor 1 tahun 1967 tentang penanaman modal asing, dan nomor 6 tahun 1968 tentang penanaman modal dalam negeri. Dimana Pasar modal sangat berpengaruh dan berperan penting dalam menunjang perekonomian. Apalagi dalam kegiatan investasi dinegara berkembang dengan kondisi pasar yang masih dangkal tentunya rentan dalam menghadapi tekanan dan gejolak eksternal yang sangat menggangu kinerja perusahaan.

Umumnya inflasi terjadi karena meningkatnya harga barang yang dapat menjatuhkan nilai mata uang. dan dapat menyebabkan merosotnya daya beli konsumen dan menurunkan laba perusahaan termasuk return saham. Tingginya inflasi tentunya akan menekan tingkat suku bunga yang diharapkan mampu meredam lajunya inflasi. Akan tetapi, besarnya tingkat suku bunga akan merugikan para pebisnis karena dapat menambah pengeluaran beban usaha sehingga stabilitas suku bunga juga sangat menentukan tinggi rendahnya harga saham perusahaan termasuk return nya. Selain itu, volatilitas pergerakan dari nilai tukar rupiah yang menguat maupun melemah akan sangat berpengaruh sensitif terhadap pergerakan saham.

Bursa efek indonesia adalah tempat perdagangan efek secara efisien seputar saham dengan akses terbuka memudahkan para investor untuk mengamati perputaran saham dalam melakukan suatu investasi dari berbagai jenis sektor usaha. Salah satunya sektor aneka industri dalam sub sektor otomotif.

Dimana perusahaan bisnis otomotif dari waktu ke waktu telah dikenal lebih oleh masyarakat sebagai kebutuhan transportasi. Sehingga sub sektor otomotif ini semakin maju dan banyak diminati sehingga dapat meningkatkan laba perusahaan termasuk return saham. Namun jika terjadi gejala inflasi, tingkat suku bunga, dan nilai tukar rupiah sangat berpengaruh terhadap minat masyarakat untuk membeli. Sehingga naik turunnya daya beli masyarakat akan mempengaruhi harga termasuk return saham

Berdasarkan dari uraian latar belakang diatas, terdapat batasan masalah dalam penelitian ini yaitu peneliti hanya menganalisis kondisi keuangan dari faktor eksternal inflasi, suku bunga, dan nilai tukar rupiah yang akan mempengaruhi jual beli saham yang dapat menekan return saham pada PT. Astra International yang terdaftar di Bursa Efek Indonesia periode 2009-2018.

\section{B. KAJIAN TEORI}

\section{Inflasi}

Inflasi adalah gejala yang timbul dari melonjaknya harga barang dan jasa yang melambung tinggi secara menerus dari waktu ke waktu yang akan berdamapak pada perusahaan dan masyarakat khususnya (Mashudi, 2017: 265).

Latumaerissa (2012:23), berbagai macam inflasi dapat dikelompokkan berdasarkan golongan dan kategorinya antara lain:

1. Tingkat keparahan inflasi itu sendiri; Inflasi ringan, yaitu berada dibawah $30 \%$ setahun, Inflasi sedang, yaitu berada antara 10\%- 30\% setahun, Inflasi berat, yaitu berada antara 30\%-100\% setahun dan hiperInflasi, yaitu berada diatas 100\% setahun.

2. Munculnya gejala inflasi yaitu karena tingginya tingkat permintaan dari masyarakat pada suatu barang (demand Inflation) dan Kenaikan ongkos produksi (Cost Inflation). 
3. Asal nya inflasi dibedakan menjadi dua yaitu berasal dari dalam negeri (Domestic Inflation), contohnnya adanya pembiayaan percetakan uang baru, gagal panen dikarenakan defisit anggaran belanja dan berasal dari luar negeri di negaranegara langganan berdagang kita (Imported Inflation).

\section{Suku Bunga}

Suku bunga adalah keuntungan investor atas dana yang diinvestasikannya dibank atau hadiah yang diperoleh karena telah menyimpan uangnya dibank. Namun disisi lain, kewajiban yang harus dibayar oleh orang yang melakukan pinjaman ke bank (Kasmir, 2015:354).

Terdapat dua jenis dalam suku bunga yaitu bunga dalam bentuk simpanan merupakan harga yang harus diberikan sebagai balas jasa yang diberikan oleh bank kepada nasabah yang menyimpan uangnya di bank. Sedangkan bunga pinjaman adalah harga yang harus diberikan pada pihak bank sebagai harga jualnya kepada peminjam (Sunariyah, 2011:80).

\section{Nilai Tukar Rupiah}

Kurs merupakan harga suatu mata uang (rupiah) negara dengan mata uang negara lain. (Ekananda , 2015:168).

Berdasarkan jenisnya kurs terdiri dari kurs jual, kurs beli, kurs tengah, dan kurs rata. Dimana jenis ini digunakan untuk tukar menukar antar mata uang sesuai dengan jenis mata uang yang dibutuhkan sebagai kegiatan dalam bertransaksi (Sukirno, 2011:411).

\section{Return Saham}

Return saham ialah pengembalian atas dana ataupun asset investasi oleh investor dengan harapan keuntungan yang diperoleh lebih besar dari yang telah diinvestasikkannya (Tandelilin, 2017:113).

Adapun Sumber-sumber return investasi yakni yield yang merupakan komponen return aliran kas atau pendapatan yang diperoleh secara periodik dari suatu investasi. Sedangkan, capital gain (loss) sebagai komponen kedua merupakan kenaikan (penurunan) harga suatu surat berharga (bisa saham maupun surat utang jangka panjang), yang bisa memberikan keuntungan (kerugian) bagi investor (Tandelilin,2017: 114).

\section{KERANGKA BERPIKIR}

Berinvestasi dinegara berkembang seringkali menimbulkan permasalahan yang dapat merugikan perusahaan bahkan para investor. Sehingga sebelum berinvestasi pastinya investor melakukan pertimbangan dari berbagai macam masalah ekonomi yang dihadapi nantinya. 


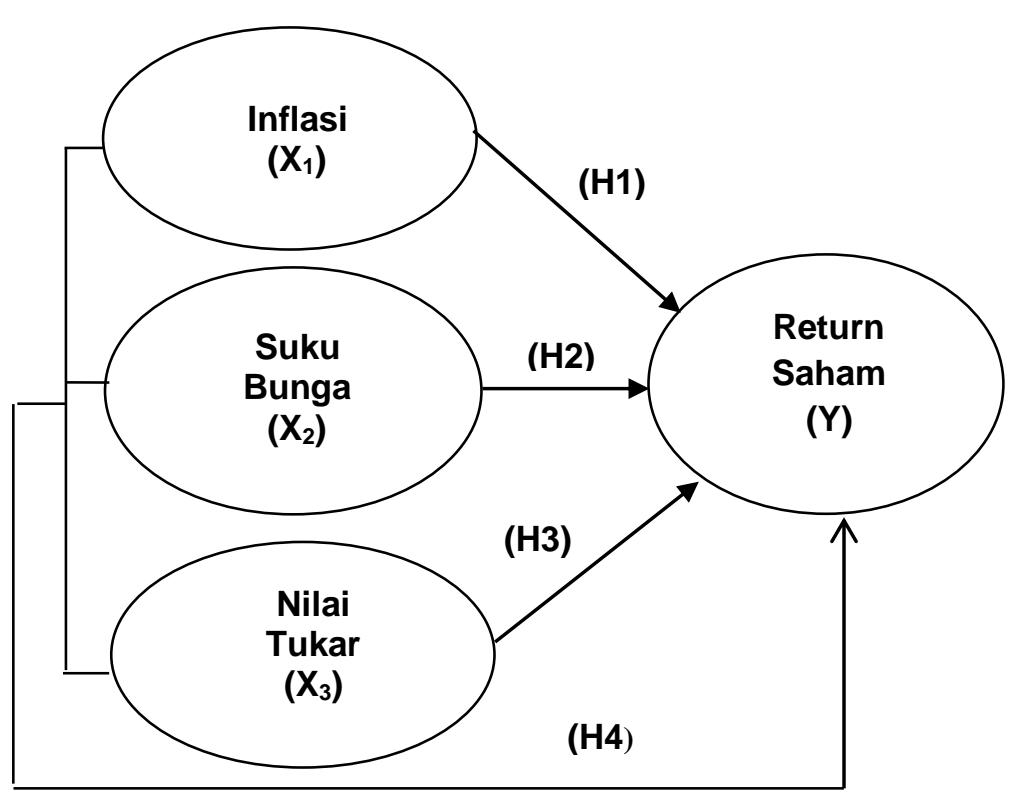

Gambar Kerangka Penelitian

Inflasi memang kerap kali memberikan hal positif yang kadang dibutuhkan. Namun, efek yang diberikan dari tingginya inflasi ini akan menyulitkan kondisi ekonomi karena meningkatnya harga yang akhirnya tidak dapat dijangkau oleh masyarakat dan diperparah jika tidak diiringi dengan tingginya tingkat daya beli masyarakat itu sendiri.

Tingkat kenaikan suku bunga berpengaruh dalam pengendalian inflasi. Ketika tingkat suku bunga tinggi dapat memberikan dampak buruk bagi para pebisnis yang pada akhir nya mengurangi investasi baru, menurunkan aktivitas perusahaan bahkan berpengaruh terhadap laba termasuk return saham.

Tingkat suku bunga juga menentukan nilai tambat mata uang suatu negara. Karena akan menarik investor yang mencari high return untuk menanamkan dananya, sehingga pemintaan terhadap mata uang pun naik.

\section{Hipotesis}

Hipotesis yang akan diteliti dan diuji dalam penelitian yaitu :

$\mathrm{H} 1$ :Terdapat pengaruh yang signifikan inflasi terhadap return saham

$\mathrm{H} 2$ :Terdapat pengaruh yang signifikan suku bunga terhadap return saham

$\mathrm{H} 3$ :Terdapat pengaruh yang signifikan nilai tukar rupiah terhadap return saham

H4 :Terdapat pengaruh yang signifikan inflasi, suku bunga, dan nilai tukar rupiah terhadap return saham.

\section{METODE PENELITIAN}

Penelitian menggunakan metode kuantitatif yang merupakan untuk meneliti pada populasi atau sampel tertentu dengan tujuan untuk menguji hipotesis yang telah ditetapkan (Sugiyono, 2016:13).

Adapun variabel yang digunakan dalam penelitian ini yaitu $\left(X_{1}\right)$ Inflasi, $\left(X_{2}\right)$ Suku Bunga, $\left(\mathrm{X}_{3}\right)$ Nilai tukar rupiah dan $(\mathrm{Y})$ Return Saham.

Berikut definisi operasional dari variabel yang digunakan dalam penelitian : 
Tabel Definisi Operasional Variabel

\begin{tabular}{|c|c|c|c|}
\hline No & Variabel & Konsep Variabel & Proxy \\
\hline 1. & Inflasi $\left(\mathrm{X}_{1}\right)$ & $\begin{array}{l}\text { Gejala yang timbul dari melonjaknya harga } \\
\text { barang dan jasa yang melambung tinggi secara } \\
\text { menerus dari waktu ke waktu yang akan } \\
\text { berdamapak pada perusahaan dan masyarakat } \\
\text { khususnya (Mashudi dkk, 2017:265). }\end{array}$ & $\begin{array}{l}\text { Data inflasi secara } \\
\text { perbulan dari Januar } \\
\text { 2009- Desember 2018 } \\
\text { yang diterbitkan oleh Bank } \\
\text { Indonesia dalam situs } \\
\text { www.bi.co.id. }\end{array}$ \\
\hline 2. & $\begin{array}{l}\text { Suku } \\
\text { Bunga }\left(X_{2}\right)\end{array}$ & $\begin{array}{l}\text { Suku bunga adalah keuntungan investor atas } \\
\text { dana yang diinvestasikannya dibank. Namun } \\
\text { disisi lain, kewajiban yang harus dibayar oleh } \\
\text { orang yang melakukan pinjaman ke bank } \\
\text { (Kasmir, 2015:354). }\end{array}$ & $\begin{array}{l}\text { Data tingkat suku bunga } \\
\text { yang diterbitkan oleh Bank } \\
\text { Indonesia dalam situs } \\
\text { resmi www.bi.co.id secara } \\
\text { perbulan dari jan2009- } \\
\text { Des } 2018 \text {. }\end{array}$ \\
\hline 3. & $\begin{array}{l}\text { Nilai Tukar } \\
\text { Rupiah }\left(\mathrm{X}_{3}\right)\end{array}$ & $\begin{array}{l}\text { Kurs merupakan harga suatu mata uang } \\
\text { (rupiah) negara dengan mata uang negara lain. } \\
\text { (Ekananda, 2015:168). }\end{array}$ & $\frac{\text { Kurs Jual }+ \text { Kurs beli }}{2}$ \\
\hline 4. & $\begin{array}{l}\text { Return } \\
\text { Saham (Y) }\end{array}$ & $\begin{array}{l}\text { Return saham ialah pengembalian atas dana } \\
\text { ataupun asset investasi oleh investor dengan } \\
\text { harapan keuntungan yang diperoleh lebih besar } \\
\text { dari yang telah diinvestasikkannya (Tandelilin, } \\
\text { 2017:113). }\end{array}$ & $\frac{P_{t}-P_{t-1}}{P_{t-1}}$ \\
\hline
\end{tabular}

Kemudian Populasi dalam penelitian ini adalah Return Saham pada PT. Astra International Tbk dan data inflasi, suku bunga, dan nilai tukar rupiah. Sedangkan sampel dalam penelitian ini menggunakan purposive judgment sampling dengan kreteria perusahaan terdaftar di BEl, listing dalam jual beli saham, dan data tersedia di BEI . Sampel dalam penelitian ini adalah harga-harga saham PT. Astra International Tbk. Data inflasi, suku bunga, dan nilai tukar rupiah periode 2009-2018 secara perbulan. Menggunakan data sekunder dengan teknik pengumpulan data melalui kajian-kajian pustaka sesuai dengan variabel penelitian. Dengan teknik analisis data yang digunakan adalah analisis kuantitatif dengan analisis liniear berganda dengan uji asumsi klasik yang digunakan sebelum uji hipotesis dilakukan untuk melihat gambaran data yang berdistribusi normal atau tidak dengan berdasarkan ketentuan signifikan nilai nya harus diatas 0,05 .

\section{Analisis Regresi Berganda}

Analisis yang dilakukan untuk mencari pengaruh secara keseluruhan variable independen terhadap dependenya (Kadir, 2018:203). Maka regresi linier ganda dinyatakan dalam persamaan sebagai berikut.

Model Regresi : $Y=\beta_{0}+\beta_{1} X_{1}+\beta_{2} X_{2}+\beta_{3} X_{3}+\varepsilon$ (Populasi)

Fungsi Regresi : $Y=b_{0}+b_{1} X_{1}+b_{2} X_{2}+b_{3} X_{3}$ (Sampel)

\section{Keterangan :}

Return Saham (Y)

Konstan $\left(b_{0}\right)$

Koerisien Regresi $\left(b_{1} b_{2} b_{3}\right)$

Inflasi $\left(\mathrm{X}_{1}\right)$

Suku bunga $\left(X_{2}\right)$

Nilai Tukar Rupiah $\left(X_{3}\right)$

Standar Eror (e). 


\section{Pengujian Hipotesis}

Uji t dalam penelitian dilakukan untuk menguji apakah benar atau tidaknya terdapat pengaruh pada masing-masing variabel bebas terhadap variabel terikat . Dan Uji statistik $F$ menguji apakah ada pengaruh antara semua variabel bebas secara bersama-sama baik inflasi, suku bunga, nilai tukar rupiah terhadap return saham sebagai variabel terikatnya (Priyatno, 2016:66).

\section{Koefisien Determinasi $\left(\mathbf{R}^{2}\right)$}

Untuk mengukur berapa besar pengaruh variabel bebas atau seberapa jauh kemampuan model dalam menerangkan variasi variabel terikat. (Kuncoro,2011:108).

\section{HASIL DAN PEMBAHASAN}

Besarnya tingkat resiko dalam berinvestasi tentu sangat mempengaruhi hasil yang diperoleh. Dimana semakin besar keuntungan yang kita inginkan artinya semakin besar juga resiko yang akan kita tanggung nantinya. Besar kecilnya return yang diinginkan dan menjadi bagian penting dalam melakukan investasi dan dapat dilihat dari statistik deskriptif dibawah ini.

Berdasarkan tabel diatas terlihat bahwa nilai inflasi mempunyai rata-rata sebesar 4,9983 dengan standar deviasi 1,76629. Tingkat suku bunga sebesar 6,2792 dengan standar deviasi 1,08086. dan nilai tukar rupiah sebesar 1142,8218 dengan standar deviasi 2012,78674. sementara return saham sebesar 2,0515 dengan standar deviasi 8,22802.

\section{Hasil Uji Prasyarat Analisis Uji Normalitas}

Uji asumsi ini memiliki tujuan apakah data yang diperoleh nilai residualnya terdistribusi secara normal atau tidak. Untuk mengetahuinya maka digunakan Kolmogrov Smirnov dengan ketentuan diatas 0,05 (Ghozali, 2014:154).

Tabel One-Sample Kolmogorov-Smirnov Test

\begin{tabular}{|c|c|c|}
\hline & & $\begin{array}{c}\text { Unstandardized } \\
\text { Residual }\end{array}$ \\
\hline $\begin{array}{l}\text { Normal Parameters }{ }^{a, b} \\
\text { Most Extreme Differences } \\
\text { Test Statistic } \\
\text { Asymp. Sig. (2-tailed) }\end{array}$ & $\begin{array}{l}\text { Mean } \\
\text { Std. Deviation } \\
\text { Absolute } \\
\text { Positive } \\
\text { Negative }\end{array}$ & $\begin{array}{r}120 \\
.0000000 \\
9.65917749 \\
.060 \\
.060 \\
-.043 \\
.060 \\
.200^{c, d}\end{array}$ \\
\hline
\end{tabular}
a. Test distribution is Normal.
b. Calculated from data.
c. Lilliefors Significance Correction.
d. This is a lower bound of the true significance. 
Tabel Descriptive Statistics

\begin{tabular}{|l|l|r|r|r|r|}
\hline & $\mathrm{N}$ & \multicolumn{1}{|c|}{ Minimum } & \multicolumn{1}{c|}{ Maximum } & \multicolumn{1}{c|}{ Mean } & Std. Deviation \\
\hline Inflasi & 120 & 2.41 & 9.17 & 4.9983 & 1.76629 \\
Suku Bunga & 120 & 4.25 & 8.75 & 6.2792 & 1.08086 \\
Nilai Tukar & 120 & 8532.00 & 15178.87 & 11429.8218 & 2012.78674 \\
Return Saham & 120 & -20.12 & 26.32 & 2.0515 & 8.22802 \\
Valid N (listwise) & 120 & & & & \\
\hline
\end{tabular}

Berdasarkan hasil uji diatas menunjukkan bahwa nilai Asymp.Sig. (2-tailed) diperoleh sebesar 0,200. Dimana nilai tersebut lebih tinggi dibanding ketentuan signifikannya sebesar 0,05 . Sehingga dapat disimpulkan bahwa seluruh residual model regresi diatas menunjukkan hasil yang terdistribusi secara normal dan memenuhi syarat asumsi normalitasnya.

\section{Uji Multikoloniearitas}

Uji Asumsi ini memiliki tujuan apakah ada hubungan antar variabel independen. Untuk melihatnya digunakan nilai tolerance dengan ketentuan harus lebih tinggi dari 0,1 dan VIF dibawah 10 (Ghozali, 2011:106).

Tabel Coefficients ${ }^{a}$

\begin{tabular}{|c|c|c|c|c|c|c|c|}
\hline \multirow[b]{2}{*}{ Model } & \multicolumn{2}{|c|}{$\begin{array}{l}\text { Unstandardized } \\
\text { Coefficients }\end{array}$} & \multirow{2}{*}{$\begin{array}{c}\begin{array}{c}\text { Standardized } \\
\text { Coefficients }\end{array} \\
\text { Beta }\end{array}$} & \multirow[b]{2}{*}{$T^{T}$} & \multirow[b]{2}{*}{ Sig. } & \multicolumn{2}{|c|}{$\begin{array}{c}\text { Collinearity } \\
\text { Statistics }\end{array}$} \\
\hline & $B$ & Std. Error & & & & Tolerance & VIF \\
\hline (Constant) & 50.128 & 7.517 & & 6.669 & .000 & & \\
\hline Inflasi & -238 & .123 & -.238 & -1.942 & .055 & .533 & 1.875 \\
\hline Suku Bunga & .319 & .124 & .319 & 2.563 & .012 & .520 & 1.923 \\
\hline Nilai Tukar & -083 & .092 & -.083 & -.901 & .369 & .950 & 1.052 \\
\hline
\end{tabular}

a. Dependent Variable: Return Saham

Dari data diatas dapat dilihat bahwa collinearity statistics nilai tolerance dari seluruh variabel independen nilai nya lebih dari 0,1 dan nilai VIF kurang dari 10 . Sehingga dapat disimpulkan bahwa tidak terjadi masalah yang menunjukkan terjadi nya multikoloniearitas sehingga memenuhi syarat dalam uji asumsinya.

\section{Uji Autokorelasi}

Asumsi dalam uji autokorelasi adalah residual yang saling berhubungan. Namun model regresi yang baik, sebaiknya tidak terjadi autokorelasi. Untuk mengetaahuinya dapat dilihat pada tabel dibawah ini.

Tabel Uji Autokorelasi
Model Summary
\begin{tabular}{|l|c|r|c|r|r|}
\hline Model & $\mathrm{R}$ & $\mathrm{R}$ Square & $\begin{array}{c}\text { Adjusted R } \\
\text { Square }\end{array}$ & $\begin{array}{c}\text { Std. Error of } \\
\text { the Estimate }\end{array}$ & $\begin{array}{c}\text { Durbin- } \\
\text { Watson }\end{array}$ \\
\hline 1 & $.259^{\mathrm{a}}$ & .067 & .043 & 9.78328 & 2.045 \\
\hline
\end{tabular}

a. Predictors: (Constant), Nilai Tukar, Inflasi, Suku Bunga

b. Dependent Variable: Return Saham

Dari data yang diperoleh dari diatas, berdasarkan ketentuan dalam Durbin Watson bahwa jika nilai du lebih kecil dari nilai dw dan lebih kecil dari nilai 4-du (du<dw<4-du) artinya tidak terjadi gejala autokorelasi. Jadi, dari hasil diatas menunjukkan bahwa nilai du sebesar 1,754 lebih kecil dari nilai dw yaitu sebesar 
2,045 dan ini lebih kecil dari nilai 4-du sebesar 2,246. Sehingga dapat disimpulkan bahwa tidak terdapat autokorelasi.

\section{Uji Heteroskedastisitas}

Asumsi dalam uji heterokedastisitas menguji apabila terdapat kesalahan atau residual dari model yang memerlukan kondisi bahwa residual adalah dari satu observasi atau observasi lain. Untuk mengetahuinya maka dilkukan dengan scatterplot ada tidaknya gejala terjadinya hesteroskedastisitas dari gambar dibawah.

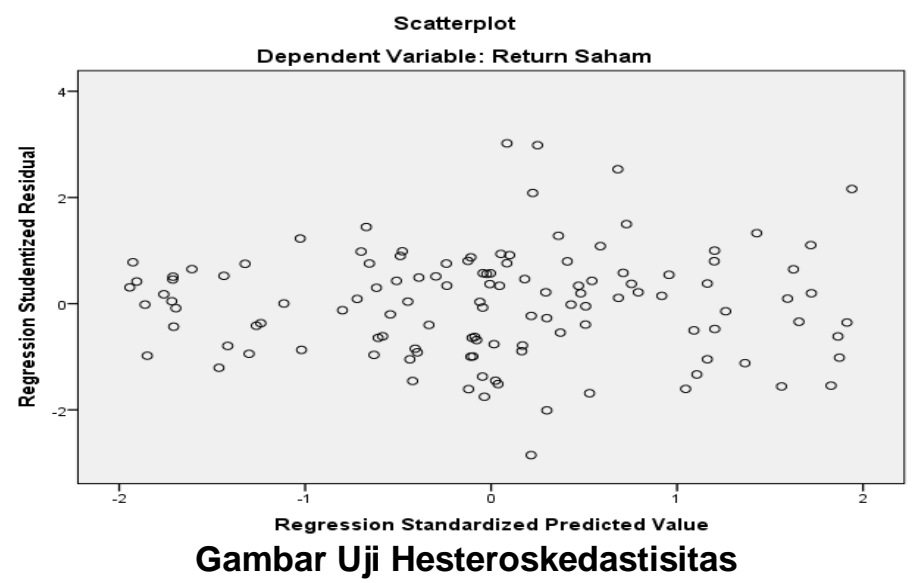

Dilihat dari gambar dibawah terlihat bahwa titik-titik data menyebar sekitaran angka 0 diatas dan dibawah serta tidak membentuk pola seperti bergelombang yang menunjukkan bahwa tidak terjadi nya heteroskedastisitas dari model data peneltian.

\section{Persamaan Regresi Berganda}

Dari hasil uji asumsi klasik yang telah dilakukan diatas, bahwa model regresi data layak digunakan sebagai penelitian karena tidak terjadi masalah dalam uji asumsinya, maka tahap selanjutnya yang akan dilakukan yaitu analisis regresi berganda yang ditunjukkan pada tabel berikut.

Tabel Persamaan Regresi Berganda Coefficients $^{\mathrm{a}}$

\begin{tabular}{|ll|r|r|r|r|r|}
\hline \multirow{2}{*}{ Model } & \multicolumn{3}{|c|}{$\begin{array}{c}\text { Unstandardized } \\
\text { Coefficients }\end{array}$} & $\begin{array}{c}\text { Standardized } \\
\text { Coefficients }\end{array}$ & & \\
\cline { 3 - 5 } & & \multicolumn{1}{|c|}{$\mathrm{B}$} & \multicolumn{1}{c|}{ Std. Error } & \multicolumn{1}{c|}{ Beta } & \multicolumn{1}{c|}{ Sig. } \\
\hline & (Constant) & 50.128 & 7.517 & & 6.669 & .000 \\
& Inflasi & -238 & .123 & -.238 & -1.942 & .055 \\
& Suku & .319 & .124 & .319 & 2.563 & .012 \\
& Bunga & -083 & .092 & -.083 & -.901 & .369 \\
\hline
\end{tabular}

a. Dependent Variable: Return Saham

Berdasarkan analisis terlihat bahwa konstanta regresi adalah sebesar 50,128. Hal ini berarti bahwa tanpa adanya pengaruh dari inflasi, suku bunga, nilai tukar rupiah maka besarnya return saham yang ditawarkan kepada investor sebesar 50,128.

Kesimpulan dari hasil regresi liniear berganda adalah sebagai berikut :

$\beta_{1}=-0,238$ merupakan koefisien regresi inflasi $\left(X_{1}\right)$, nilainya menunjukkan hasil negatif yang artinya jika inflasi naik sebesar 100\%, maka return saham PT. 
Astra International tbk turun sebesar -0,238 dengan asumsi varibel lainnya konstan.

$\beta_{2}=0,319$ merupakan koefisien regresi suku bunga $\left(X_{2}\right)$, nilai nya menunjukkan hasil positif yang artinya jika suku bunganya naik sebesar $100 \%$, maka Return Saham PT. Astra International tbk akan juga naik sebesar 0,319 dengan asumsi variabel lainnya konstan.

$\beta_{3}=-0,083$ merupakan koefisien regresi nilai tukar $\left(X_{3}\right)$, nilanya menunjukkan hasil negatif yang artinya jika nilai tukar meningkat $100 \%$ maka Return Saham PT. Astra International tbk akan menurun sebesar $-0,083$ dengan asumsi variabel lainnya konstan.

\section{Pengujian Hipotesis Uji Parsial}

Uji $t$ dalam penelitian dilakukan untuk menguji apakah benar atau tidaknya terdapat pengaruh pada masing-masing variabel bebas terhadap variabel terikat (Priyatno, 2016:66).

Pengujian hipotesis masing-masing secara parsial variabel independen terhadap dependen dapat dianalisis sebagai berikut :

Tabel Hasil Uji Hipotesis

Coefficients $^{\mathrm{a}}$

\begin{tabular}{|ll|r|r|}
\hline & & & \\
\hline 1 & & \multicolumn{1}{|c|}{$\mathrm{T}$} & \multicolumn{1}{c|}{ Sig. } \\
\hline & Constant & 6.669 & .000 \\
& Inflasi & -1.942 & .055 \\
& Suku Bunga & 2.563 & .012 \\
& Nilai Tukar & -.901 & .369 \\
\hline
\end{tabular}

a. Dependent Variable: Return Saham

\section{Pengaruh Inflasi terhadap Return Saham}

Dari hipotesis pertama diperoleh hasil regresi yang menunjukkan tingkat signifikan dari thitung untuk variabel inflasi terhadap return saham adalah sebesar 1,942 dengan nilai probabilitas 0,055 yang cenderung lebih besar dari nilai ketentuan signifikan sebesar 0,05 yang artinya tidak terdapat pengaruh signifikan dari nilai inflasi terhadap return saham pada PT.Astra International Tbk.

Inflasi yang tidak terlalu tinggi justru dapat meningkatkan pertumbuhan sehingga perusahaan dapat menyesuaikan kenaikan harga dengan biaya produksinya dan tidak terlalu berimbas pada laba termasuk return saham itu sendiri. Namun jika nilai inflasi yang terlalu tinggi atau terjadi hiperinflasi baru dapat menyebabkan turunnya sumber daya beli konsumen karena kenaikan akan harga barang-barang yang dapat memberikan dampak buruk terhadap laba perusahaan dan juga dapat mempengaruhi hasil return nya. Semakin optimal nya nilai inflasi maka cenderung dapat menurunkan return saham nya dan sebaliknya semakin kecil nilai inflasi nya maka cenderung semakin besar return sahamnya.

\section{Pengaruh Suku Bunga terhadap Return Saham}

Dari hipotesis kedua hasil analisis data diperoleh nilai yang menunjukkan thitung dari suku bunga adalah sebesar 2,563 dengan nilai probabilitas sig 0,012 yang cenderung lebih kecil dari ketentuan nilai signifikansinya 0,05 yang artinya terdapat 
pengaruh yang signifikan dari nilai suku bunga terhadap return saham pada PT.Astra International Tbk.

Hasil penelitian ini sejalan dengan penelitian yang dilakukan oleh Wiradharma (2016) yang mendukung bahwa suku bunga berpengaruh positif terhadap return saham. Karena besarnya tingkat bunga dapat menambah biaya modal yang harus ditanggung perusahaan dan dapat menyebabkan return aktual investor meningkat. Sebagai perusahaan jaringan bisnis otomotif, PT.Astra International Tbk selalu menjadi kebutuhan transportasi disetiap kalangan masyarakat sehingga investor akan tetap berinvestasi meskipun tingkat suku bunga deposito meningkat.

\section{Pengaruh Nilai Tukar $\left(\mathbf{X}_{3}\right)$ terhadap Return Saham $(\mathbf{Y})$}

Dari hipotesis ketiga hasil analisis data diperoleh nilai yang menunjukkan thitung $_{\text {na }}$ untuk variabel nilai tukar rupiah terhadap return saham sebesar -0,901 dengan probabilitas sig 0,369 yang lebih besar dari ketentuan signifikansinya 0,05 yang artinya tidak terdapat pengaruh signifikan dari variabel nilai tukar rupiah terhadap return saham PT.Astra International Tbk.

Besarnya nilai tukar rupiah dapat menurunkan return saham. Akan tetapi, dalam penelitian ini tidak memberikan pengaruh signifikan sehingga dapat ditunjukkan bahwa fluktuatif nya nilai tukar rupiah belum mempengaruhi return pada saham PT. Astra International tbk.

Hasil penelitian ini sejalan dengan penelitian yang dilakukan oleh Elvinia Wahyuningih (2018) yang membuktikan bahwa nilai tukar rupiah tidak berpengaruh signifikan terhadap return saham. Karena tinggi rendahnya nilai tukar tidak menjadikan laba atas keseluruhan dari asset yang dimiliki juga ikut besar. Oleh karena itu, tinggi rendahnya nilai kurs tidak berpengaruh terhadap return pada saham PT. Astra International tbk.

\section{Uji Simultan (F)}

Dan Uji statistik F menguji apakah ada pengaruh antara semua variabel bebas secara bersama-sama baik inflasi, suku bunga, nilai tukar rupiah terhadap return saham sebagai variabel terikatnya (Priyatno, 2016:66).

Tabel Uji F (Silmultan)

ANOVA $^{\mathrm{a}}$

\begin{tabular}{|rl|r|r|r|r|r|}
\hline \multicolumn{1}{|l|}{ Model } & Sum of Squares & Df & Mean Square & F & Sig. \\
\hline 1 & Regression & 797.335 & 3 & 265.778 & 2.777 & $.044^{\text {b }}$ \\
& Residual & 11102.665 & 116 & 95.713 & & \\
Total & 11900.000 & 119 & & & \\
& & & & & \\
\hline
\end{tabular}

a. Dependent Variable: Return Saham

b. Predictors: (Constant), Nilai Tukar, Inflasi, Suku Bunga

Berdasarkan dari tabel diatas bahwa nilai $F_{\text {hitung }}$ sebesar 2,777 dengan nilai probabilitas sebesar 0,044 yang menunjukkan bahwa nilai tersebut lebih rendah dari ketentuan nilai signifikan sebesar 0,05 sehingga dapat disimpulkan bahwa variabel independen inflasi, suku bunga, nilai tukarrupiah memiliki pengaruh yang signifikan terhadap return saham. 
Dalam hasil penelitian yang peneliti lakukan ini sejalan dengan penelitian yang dilakukan oleh Akbar Faoriko (2013) yang membuktikan bahwa secara simultan inflasi, suku bunga, nilai tukar rupiah berpengaruh terhadap return saham.

\section{Koefisien Determinasi $\left(\mathbf{R}^{2}\right)$}

Penelitian ini mengukur seberapa jauh kemampuan model dalam menerangkan variasi variabel dependen. yang ditunjukkan pada tabel berikut.

\begin{tabular}{l}
\multicolumn{8}{c}{$\begin{array}{c}\text { Tabel Uji Koefisien Determinasi } \\
\text { Model Summary }\end{array}$} \\
\begin{tabular}{|l|c|r|r|c|}
\hline Model & $R$ & R Square & $\begin{array}{c}\text { Adjusted R } \\
\text { Square }\end{array}$ & $\begin{array}{c}\text { Std. Error of the } \\
\text { Estimate }\end{array}$ \\
\hline 1 & $.259^{\mathrm{a}}$ & .067 & .043 & 9.78328 \\
\hline
\end{tabular}
\end{tabular}

a. Predictors: (Constant), Nilai Tukar, Inflasi, Suku Bunga

b. Dependent Variable: Return Saham

Dari hasil uji diatas maka diperoleh nilai $\mathrm{R}$ berjumlah 0,259 yang diartikan bahwa hubungan inflasi, suku bunga, nilai tukar rupiah dengan return saham adalah sedang. Maksudnya jika ada peningkatan hubungan variabel Inflasi, Suku Bunga, Nilai Tukar maka diikuti dengan peningkatan return saham. dan hubungan variabel Inflasi, Suku Bunga dan Nilai Tukar mampu mempengaruhi return saham hanya sebesar 4,3\%, sedangkan sisanya sebesar $95,7 \%(100-4,3)$ disumbangkan oleh faktor lain diluar penelitian.

\section{E. KESIMPULAN DAN SARAN}

1) Kesimpulan

Berdasarkan dari olah data serta informasi yang ada maka hasil dari penelitian yang penulis kemukakan pada bab-bab sebelumnya dapat diambil kesimpulan penting, yaitu :

1. Hasil pengujian secara parsial (uji t) yang membuktikan bahwa nilai thitung untuk variabel independen inflasi terhadap return saham sebesar -1,942 dengan probabilitas sig 0,055 lebih tinggi dari ketentuan signifikannya $(0,05)$ sehingga $\mathrm{H}_{0}$ diterima dan $\mathrm{H}_{\mathrm{a}}$ ditolak yang berarti tidak ada pengaruh dari inflasi terhadap return saham PT. Astra International Tbk. Namun hasil regresi yang bernilai negatif tersebut mampu membuktikan bahwa tinggi nya tingkat inflasi dapat menurunkan return saham.

2. thitung dari Suku Bunga (X2) sebesar 2.567 dengan probabilitas sig 0,012 lebih rendah dari ketentuan signifikannya $(0,05)$ sehingga $\mathrm{H}_{0}$ ditolak dan $\mathrm{H}_{\mathrm{a}}$ diterima yang berarti terdapat pengaruh signifikan $\mathrm{X}_{2}$ (Suku Bunga) terhadap $\mathrm{Y}$ (Return Saham) pada PT. Astra International tbk. Pengaruh yang diberikan dari regresi tersebut bernilai positif yang membuktikan bahwa tinggi nya tingkat suku bunga dapat meningkatkan return sahamnya. Sedangkan

3. Nilai Tukar Rupiah $\left(X_{3}\right)$ yang membuktikan bahwa variabel ini dengan thitung nya sebesar -0,901 dengan probabilitas sig 0,369 lebih tinggi dari ketentuan signifikannya (005) sehingga $\mathrm{H}_{0}$ diterima dan $\mathrm{H}_{\mathrm{a}}$ ditolak yang berarti tidak berpengaruh signifikan namun hasil yang bernilai negatif mampu membuktikan bahwa tinggi nya nilai tukar dapat menurunkan return saham.

4. Hasil pengujian secara simultan (uji F) yang membuktikan bahwa hasil signifikan inflasi, suku bunga, nilai tukar rupiah terhadap return saham sebesar 
0,044 yang memiliki nilai sig lebih rendah dari nilai ketentuan signifikannya yaitu sebesar 0,05 yang berarti terdapat pengaruh signifikan terhadap return saham.

\section{2) SARAN} adalah :

Adapun saran yang peneliti berikan terkait dari hasil penelitian diantaranya

1. Inflasi yang tinggi mampu menjadi penyebab menurunnya laba perusahaan. Oleh karena itu agar perusahaan terhindar dari gejala inflasi. Ada baiknya melakukan strategi dan inovasi yang dapat meningkatkan kinerja perusahaan sehingga keuangan perusahaan stabil dan tidak rentan terhadap tekanan dari tingginya inflasi.

2. Pendapatan atau laba perusahan yang tinggi menjadi minat investor untuk berinvestasi meskipun tingkat suku bunga tinggi. Oleh karena itu, pentingnya bagi perusahaan untuk meningkatkan kualitas usaha dan menjaga kestabilan laba yang mampu menarik para investor untuk berinvestasi.

3. Stabilitas Nilai tukar rupiah yang tidak baik dapat memberi dampak buruk bagi perusahaan maupun investor. Oleh karena itu, untuk menghindari kerugian. Ada baiknya perusahaan melakukan perbaikan secara struktural dalam mengembangkan usahanya yang mampu meningkatkan perusahaan. Sehingga kuat terhadap tekanan pergerkan nilai tukar.

4. Agar terhindar dari kerugian dalam penggunaan aset lancar perusahaan. Ada baiknya mempertimbangkan segala bentuk resiko sebelum memutuskan untuk berinvestasi. Sangat penting untuk memperhatikan jenis investasi dan gejalagejala ekstrenal yang dapat menjatuhkan nilai daya beli masyarakat yang mengurangi pendapatan rill investor dalam berinvestasi.

\section{DAFTAR PUSTAKA}

Ekananda, Mahyus. (2015). Ekonomi International. Jakarta: Erlangga.

Faoriko, Akbar. (2013). Pengaruh Inflasi, suku bunga, nilai tukar terhadap retrun saham pada perusahaan manufaktur di Bursa Efek Indonesia. Skripsi. Yogyakarta: Universitas Negeri Yogyakarta.

Ghozali, Imam. (2011). Aplikasi Analisis Multivariat dengan Program SPSS. Edisi Ketujuh. Semarang: Badan Penerbit Universitas Diponegoro.

Ghozali, Imam. (2014). Aplikasi Analisis Multivariat dengan Program SPSS. Semarang: Badan Penerbit Universitas Diponegoro.

Kadir. (2018). Statistika Terapan. Depok: PT. Rajagrafindo Persada.

Kasmir. (2015). Dasar-dasar Perbankan. Edisi Revisi 2014. Jakarta: PT. Rajagrafindo

Kuncoro, Mudrajad. (2011). Metode Kuantitatif. Yogyakarta: UPP STIM YKPN. 
Latumaerissa, Julius R. (2012). Bank dan Lembaga Keuangan Lain. Jakarta: Salemba.

Mashudi, Djohan dkk. (2017). Pengantar Teori Ekonomi. Yogyakarta: Gosyen Publishing.

Priyatno, Duwi. (2016). SPSS Panduan Mudah Olah Data Bagi Mahasiswa \& Umum. Yogyakarta : ANDI.

Sugiyono. (2016). Metode Penelitian Kuantitatif Kualitatif dan Kombinasi (Mixed Methods). Bandung: Alfabeta.

Sukirno, Sadono. (2011). Pengantar Teori Makro Ekonomi. Jakarta: PT. Raja Grafindo Persada.

Sunariyah. (2011). Pengantar Pengetahuan Pasar Modal. Yogyakarta: Sekolah Tinggi IImu Manajemen YKPN.

Tandelilin, Erduardus. (2017). Pasar Modal. Yogyakarta: PT. Kanisius.

Wahyuningsih, Elvina. (2018). Pengaruh Tingkat Suku Bunga dan Inflasi terhadap Return Saham dengan Nilai Tukar Rupiah sebagai Variabel Intervening (Studi Kasus pada PT. Astra International yang terdaftar di Bursa Efek Indonesia periode 2011-2015). Jurnal of Accounting 2018. Fakultas Ekonomi Universitas Pandanaran Semarang.

Wiradharma, Made Satria dan Luh Komang Sudjarni. (2016). Pengaruh Tingkat Suku Bunga, Tingkat Inflasi, Nilai Kurs Rupiah dan Produk Domestik Bruto terhadap Return Saham. Jurnal Manajemen Unud, Vol 5, No 6, 2016.

www. bi.go.id Diakses pada 12 Februari 2020. 